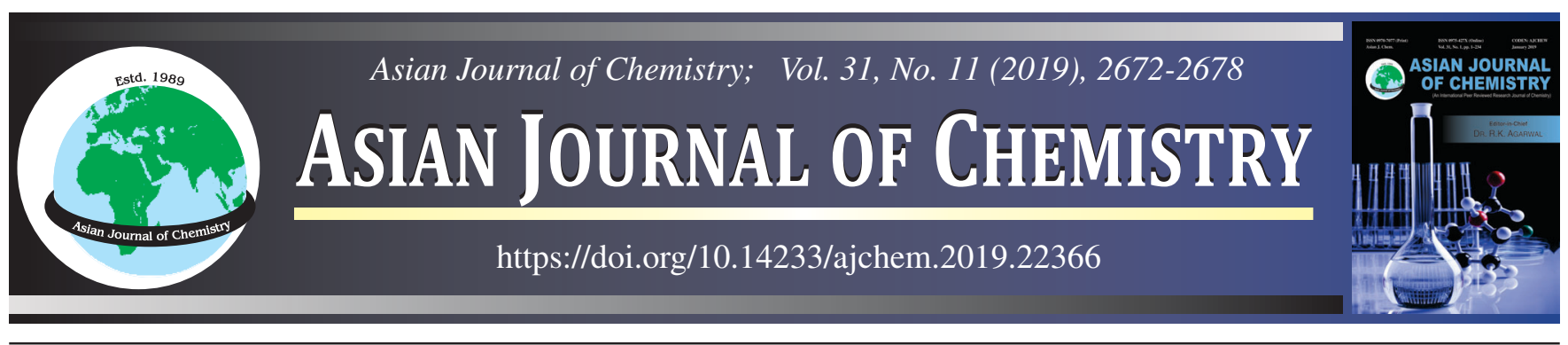

\title{
Phytochemical Contents, Antimicrobial and Antioxidant Properties of Gnaphalium uliginosum L. Ethanolic Extract and Essential Oil for Agricultural Uses
}

\author{
Sharonova Natalia Leonidovna*, ${ }^{*}$ Terenzhev Dmitriy Alexandrovich, Bushmeleva Kseniya Nikolayevna, \\ Gumerova Syubelya Kamilevna, Lyubina Anna Pavlovna, Fitsev Igor' Mikhaylovich and Belov Timur Gennad'yevich
}

Federal State Budgetary Institution of Science Federal Research Center, Kazan Scientific Center of Russian Academy of Sciences, 2/31 Lobachevskogo U1., Kazan 420111, Russia

*Corresponding author: E-mail: lapanovich@mail.ru

Received: 1 August 2019;

Accepted: 13 September 2019;

Published online: 28 September 2019;

AJC-19605

\begin{abstract}
Gnaphalium uliginosum L. (Asteraceae) is widely used in phytotherapy and has a potential for agricultural utilization. The ethanolic extract was obtained from the maceration of air-dried plants, and the extract was then filtered and concentrated using a rotary evaporator. The essential oil was pressed from freshly harvested and crushed, aerial part of plants. The chemical compositions of ethanolic extract and essential oil of G. uliginosum L. (EOG) were investigated using gas chromatography/mass spectrometry (GC/MS). Nine constituents accounted for $77.3 \%$ of the total detected components were determined at the ethanolic extract with a high proportion of sterols $42.8 \%$, fatty acids $24.1 \%$, triterpenes $14.4 \%$. Twenty constituents were identified in essential oil of G. uliginosum L.; with $\alpha$-pinene and estragole accounting for $54.0 \%$. The ethanolic extract was found to have a moderate antimicrobial activity (MIC values varied from 125 to $500 \mu \mathrm{g} / \mathrm{mL}$ ), for $S$. aureus, B. cereus and A. solani significant activity (less than $62.5 \mu \mathrm{g} / \mathrm{mL}$ ). The essential oil was found to have a moderate (MICs 500-1000 $\mu \mathrm{g} / \mathrm{mL}$ ) and strong activities $(31.3-250 \mu \mathrm{g} / \mathrm{mL})$. The antioxidant activity was evaluated using chemiluminescent assay. The ethanolic extract of G. uliginosum L. acted as a medium-strength antioxidant at concentrations of less than $0.1 \mathrm{mg} / \mathrm{mL}$. The essential oil made be regarded as a weak strength antioxidant.
\end{abstract}

Keywords: Gnaphalium uliginosum L., Ethanolic extract, Essential oil, Antimicrobial activity, Antioxidant activity.

\section{INTRODUCTION}

Plants are a rich source of active chemicals compounds that have tremendous potential for applications in agriculture. Plant bacterial and fungal pathogens attack most crops in the field and also post-harvest, thereby decreasing production and shelf life of many agricultural crops [1]. Searching for antimicrobial drugs of herbal origin with comprehensive action is extremely important for the cultivation of agricultural plants in accordance with the principles of sustainable agriculture and ecological farming systems. There are a number of studies [2-4] in the field of antimicrobial susceptibility which test different herbal extracts against human pathogenic microorganisms for medical purposes.

There is significantly less data concerning the effects of plant extracts and essential oils on phytopathogens. The control and management of phytopathogenic microorganisms through the use of natural antimicrobials has proved to be a reliable alternative to chemical fungicides and bactericides [2,5-7]. Asteraceae plants have great potential as sources of antimicrobial, antioxidant and other bioactive compounds. The genus Gnaphalium, belonging to Asteraceae, comprises approximately 300 species all over the world, among which 12 species grow in the Russian Federation [8]. The Gnaphalium species is distinguished by its polymorphism, so this ability of the genus is the subject of discussion. It belongs to a group of plants that are extremely responsive to even minor changes in their environments. Gnaphalium uliginosum L. (syn Filaginella uliginosa L.), normally named Marsh Cudweed, is an annual plant. It is widely used as a medicinal plant in folk medicine [9]. Pharmacological studies of species of the genus Gnaphalium have identified its antihistamine, antibacterial, antifungal, antioxidant, antiinflammatory, anticomplement and xanthine oxidase inhibitory properties [10-13].

The search for plants' secondary compounds, as a potential source of active elements in the formulation of new antibacterial

This is an open access journal, and articles are distributed under the terms of the Attribution 4.0 International (CC BY 4.0) License. This license lets others distribute, remix, tweak, and build upon your work, even commercially, as long as they credit the author for the original creation. You must give appropriate credit, provide a link to the license, and indicate if changes were made. 
and antifungal substances is very important. The need for sustainable agriculture and ecological farming systems and the increasing antibiotic resistance of pathogenic microorganisms to plant protection products has necessitated a search for alternative methods for phytopathogen control. The data presented should make a further contribution to the current knowledge regarding the phytochemical composition and antibacterial, antioxidant properties of G. uliginosum and help to show its potential usefulness for agriculture.

Therefore, the objectives of this study are several folds: (i) To investigate the phytochemical content of G. uliginosum L. ethanolic extract and essential oil; (ii) To determine and compare the antimicrobial activities of Gnaphalium uliginosum L. ethanolic extract and essential oil against human pathogens and phytopathogens (bacteria and fungus); and (iii) To examine the antioxidant properties of G. uliginosum L. ethanolic extract and essential oil.

\section{EXPERIMENTAL}

Plant material: Gnaphalium uliginosum L. was collected from Vasilyevo village, in Zelenodolsk district of the Republic of Tatarstan, Russian Federation, between the end of July and the beginning of August 2018. The plant material was identified by Dr. Firdaus Mukhametovna Khaziyeva, All-Russian Scientific Research Institute of Medicinal and Aromatic Plants (Moscow, Russia). Voucher specimens have been deposited at the herbarium in the same institution. The aerial parts of plants were carefully harvested at flowering stage of growth.

Preparation of Gnaphalium uliginosum L. ethanolic extract: Air-dried Gnaphalium uliginosum L. $\left(23-27^{\circ} \mathrm{C}, 15\right.$ days) was crushed into powder with a laboratory mill (LM 202, Russia). The powder $(100 \mathrm{~g})$ was added to ethanol $(500 \mathrm{~mL}$, $96 \%, \mathrm{v} / \mathrm{v})$. Then, it was macerated for $1.5 \mathrm{~h}$ at $45^{\circ} \mathrm{C}$ while being stirred. The mixture was filtered (Whatman No. 1), then the filtrate was concentrated using a rotary evaporator (LabTex Re 100 -Pro) at $35^{\circ} \mathrm{C}, 2.5 \mathrm{~mm}$ m.c. with a yield of $35 \%$ and stored at $4{ }^{\circ} \mathrm{C}$ for further research.

Obtention of G. uliginosum L. essential oil: Freshly harvested and crushed leaves and flowers of G. uliginosum L. (5 $\mathrm{kg}$ ) were pressed for $3 \mathrm{~min}$ in a 20t Hydraulic Press Machine (Prom-1, Russia). Then the liquid was transferred to a separatory funnel for separation. A mixture of hexane and chloroform (1:1) in an equal amount to pressed essential oil was used as a solvent for separation. The yield obtained was at the ratio of $1 \mathrm{~mL}$ from $1 \mathrm{~kg}$. The obtained essential oil of G. uliginosum L. (EOG) was stored in argon, in a bottle at $4{ }^{\circ} \mathrm{C}$ until used.

GC-MS analysis conditions: The mass-spectra (EI, $70 \mathrm{eV}$, $m / z=30-550 ; \mathrm{CI}, 30 \mathrm{eV}, \mathrm{m} / z=100-550)$ of EtOH extract and EOG were registered at the GC-MS "Agilent 6890N" with 5973 N Mass Selective Detector (Agilent Technologies, USA) using a silica capillary column Restek-5 MS (5\% biphenyl, $95 \%$ dimethylpolysiloxane, $30 \mathrm{~m} \times 0.25 \mathrm{~mm}$ I.D., $0.25 \mu \mathrm{m}$ film thicknesses (Restek, Germany). The GC separation conditions: evaporation temperature: $250^{\circ} \mathrm{C}$; interface temperature: $290^{\circ} \mathrm{C}$; initial thermostat temperature: $75^{\circ} \mathrm{C}$ ( 2 min dwell time); rate of column temperature rise: $10^{\circ} \mathrm{C} / \mathrm{min}$; final column temperature $280{ }^{\circ} \mathrm{C}$; column flow rate of carrier gas: (He, $\left.99.999 \%\right) 0.9$ $\mathrm{mL} / \mathrm{min}$; split injection: 40:1; sample volume: $1 \mathrm{~mL} / \mathrm{min}$. Isobutane $(99.999 \%)$ was used as the reactant gas for CI.

\section{Antimicrobial assays}

Drugs for antimicrobial assay: Norfloxacin (Sigma-Aldrich Co., USA), Ketoconazol (Sigma-Aldrich Co., USA), Chloramphenicol (Kazan Pharmaceutical Factory, Russia) and Difenoconazole (Score 250 EC, Syngenta, USA) were used as reference compounds in the tests: $5 \mathrm{mg}$ of norfloxacin, chloramphenicol, ketoconazol or difenoconazolewas dissolved in $0.5 \mathrm{~mL}$ sterile dimethylsulfoxide (DMSO, PanEco Co., Russia), then $9.5 \mathrm{~mL}$ liquid nutrient broth was added.

Microbial strains and culture media: The following strains were used: standard bacterial strains of human pathogens Pseudomonas aeruginosa 9027, Staphylococcus aureus 209P, Escherichia coli F50, Bacillus cereus 8035 and fungi: Candida albicans 885653 obtained from the state collection of pathogenic microorganisms of Tarasevich State Institute of Standardization and Control of Biomedical Preparations; the phytopathogenic bacterial strains viz., Agrobacterium tumefaciens A-47, Erwinia amylovora S59/5, Erwinia carotovora spp. carotovora SCC3193, Xanthomonas arboricola $\mathrm{S} 3$ and the phytopathogenic fungi viz. Alternaria solani St108, Fusarium graminearium PH-1, Fusarium culmorum 3288, Phytophtora sp. They were cultured in standard sterile nutritive broths: Hottinger broth for the human pathogen bacteria, Saburo medium for the human pathogen fungus and potato extract glucose broth for phytopathogenic microorganisms. The bacteria concentration was determined using a DEN1B densitometer (Biosan, Latvia) according to standard protocols.

in vitro Antimicrobial assay: The minimal inhibitory concentration (MIC) of a compound, which decreases the growth of the corresponding test microbe, was regarded as an active dose. The minimal bactericidal concentration (MBC) and minimal fungicidal concentration (MFC), respectively was the minimal concentration which caused cell death [7], in $\mu \mathrm{g} / \mathrm{mL}$ values, it was found by a two-fold serial dilution technique [14], with modification done as required [15]. The fungistatic activity of alcohol extract and essential oil was determined using a serial dilution technique [16] in liquid medium.

Liquid broth with microbial spores was prepared in standard nutritive media viz., Hottinger broth for human pathogen bacteria, Saburo medium for human pathogen fungi and potato extract glucose broth for phytopathogenic microorganisms from $24 \mathrm{~h}$ old bacterial cultures while for fungal spores from 7 to 14 dayold slant cultures were used, respectively.

The final inoculums size was $10^{5} \mathrm{cfu} / \mathrm{mL}$ for the antibacterial assay and $1.1-1.5 \times 10^{2} \mathrm{cfu} / \mathrm{mL}$ for the antifungal assay. Testing was performed at $\mathrm{pH} 7.4 \pm 0.2$ for bacteria and at $\mathrm{pH}$ 5.6 for fungi in standard nutritive media.

Exactly $2.4 \mathrm{~mL}$ of $2.5 \% \mathrm{EtOH}$ extract was dissolved in $3.6 \mathrm{~mL}$ of liquid nutrient broth to form the first dilution (final concentration of extract, $1 \%$ ). The $60 \mu \mathrm{L}$ of EOG was dissolved in $5.94 \mathrm{~mL}$ of liquid nutrient broth containing $2.5 \%$ Tween-20 (Sigma-Aldrich Co., USA) to form the first dilution (final EOG concentration, $1 \%)$. This dilution $(3 \mathrm{~mL})$ was further diluted with $3 \mathrm{~mL}$ of seeded broth to give the second dilution and so on till ten such dilutions were obtained. In the case of fungi, a piece of fungi mycelium was added to each tube. A set of assay tubes containing only seeded broth was kept as control.

To obtain minimal bactericidal and fungicidal concentrations (MBC and MFC, respectively), $10 \mu \mathrm{L}$ of inoculums (or 
a piece of fungi mycelium) taken from test tubes without visible growth were added to petri-dishes with an agarized nutrient medium using a bacteriological loop. The results were recorded every $24 \mathrm{~h}$ for 5 days at $37^{\circ} \mathrm{C}$ for Pseudomonas aeruginosa 9027, Escherichia coli F50, Staphylococcus aureus 209P, Bacillus cereus $8035,30^{\circ} \mathrm{C}$ for Agrobacterium tumefaciens A-47, Erwinia amylovora S59/5, Erwinia carotovora spp. carotovora SCC3193 and $25{ }^{\circ} \mathrm{C}$ for Xanthomonas arboricola $\mathrm{S} 3$, respectively. The exposure time of fungi with the thermostat at $26^{\circ} \mathrm{C}$ with the corresponding compound was 14 days. The microbial growth was determined visually [17]. All assays were performed in triplicates.

Antioxidant activity: The antiradical properties of $\mathrm{EtOH}$ extract and EOG were evaluated using a chemiluminescent assay $[18,19]$ using a chemiluminometer "Lum-100"("DISoft", Russia). A luminol solution (Alfa Aesar, UK) $1 \mathrm{mmol} / \mathrm{L}$ was prepared by dissolution in $0.1 \mathrm{M} \mathrm{NaOH}$; before the analysis it was diluted with distilled water four times.

The reaction mixture contained $400 \mu \mathrm{L}$ of $250 \mu \mathrm{M}$ luminol, $500 \mu \mathrm{L}$ of $0.5 \mathrm{M}$ tris buffer solution (Fisher Chemical, UK) pH 8.6 and $100 \mu \mathrm{L}$ of $40 \mathrm{mM}$ AAPH solution 2,2'-azobis(2-methylpropionamidine) dihydrochloride (Acros Organics, USA) in distilled water and incubated at $30^{\circ} \mathrm{C}$. The basic level of chemiluminescent was measured for $10 \mathrm{~min}$. Then $10 \mu \mathrm{L}$ of test compound solution was added to the reaction mixture, the level of chemiluminescent was measured during a time period of 20-30 $\mathrm{min}$. The ethanolic extract was diluted in distilled water to 10 , 1, 0.1 and $0.01 \mathrm{mg} / \mathrm{mL}$; EOG was diluted EtOH (96 \%, v/v) to
10, 1, 0.1 and $0.01 \mathrm{mg} / \mathrm{mL}$. Trolox (6-hydroxy-2,5,7,8-tetramethylchroman-2-carboxylic acid) (Sigma-Aldrich Co., USA) and quercetin were used as standard antioxidants.

For estimation of chemiluminescent value of the samples, TAR (total antioxidant reactivity) and TRAP (total reactive antioxidant potential) measurements were calculated [20]. Based on the area measurement of chemiluminescent curves, there were estimated the relative inhibitory activity of each sample. The inhibition ratio (\%) was calculated using eqn 1 :

$$
\text { Inhibition }(\%)=\frac{100 \times \mathrm{AUC}_{1}}{\mathrm{AUC}_{0}}
$$

where $\mathrm{AUC}_{0}$ and $\mathrm{AUC}_{1}$ represent the area under the curve observed for control and in the presence of sample solution, respectively. The results were processed using the PowerGraph program (http://www.powergraph.ru) and Origin Lab.

\section{RESULTS AND DISCUSSION}

Phytochemical composition of ethanolic extract and essential oil of $\boldsymbol{G}$. uliginosum L.: The ethanolic extract was characterized by GC-MS (Table-1) and consisted of aromatic compounds (aldehydes, alcohols) $5.92 \%$, fatty acids $24.09 \%$, carboxylic acid ester $2.58 \%$, ketones $0.68 \%$, alcohols $0.78 \%$, heterocyclic compounds $1.94 \%$, phenylpropanoids $0.84 \%$, oxygen-containing monoterpenes $0.93 \%$, diterpenols $3.75 \%$, triterpenes $14.41 \%$, sterols $42.82 \%$. Thirty-one compounds were identified in G. uliginosum L. ethanolic extract. Nine constituents accounted for $77.3 \%$ of total detected components.

TABLE-1

CHEMICAL COMPOSITION OF Gnaphalium uliginosum L. ETHANOLIC PLANT EXTRACT

\begin{tabular}{|c|c|c|}
\hline Constituent & $\mathrm{RR}_{\mathrm{t}}$ & $\%$ of total \\
\hline Benzeneacetaldehyde & 5.40 & 0.58 \\
\hline 4-Oxepincarboxylic acid, 2,3,6,7-tetrahydro-, ethyl ester & 6.11 & 0.46 \\
\hline 4H-Pyran-4-one, 2,3-dihydro-3,5-dihydroxy-6-methyl- & 6.77 & 1.17 \\
\hline 5-Chloropentanoic acid, 2-chlorophenyl ester & 7.73 & 0.63 \\
\hline trans-Ascaridol glycol & 8.64 & 0.47 \\
\hline 2-Hydroxy-5-methylbenzaldehyde & 10.35 & 2.01 \\
\hline Dodecanoic acid & 11.40 & 1.55 \\
\hline Benzenepropanol, 4-hydroxy-3-methoxy- & 12.46 & 3.33 \\
\hline Chinic acid & 12.62 & 1.95 \\
\hline (E)-Coniferyl alcohol & 13.38 & 0.41 \\
\hline Gallacetophenone-4'-methylether & 13.62 & 0.61 \\
\hline Neophytadiene & 13.88 & 3.07 \\
\hline 2-Pentadecanone, 6,10,14-trimethyl- & 13.97 & 0.68 \\
\hline 3,7,11,15-Tetramethyl-2-hexadecen-1-ol & 14.09 & 0.78 \\
\hline Pentadecanoic acid & 14.19 & 0.68 \\
\hline$n$-Hexadecanoic acid & 15.12 & 19.91 \\
\hline Hexadecanoic acid, ethyl ester & 15.23 & 0.57 \\
\hline Scopoletin & 15.45 & 0.43 \\
\hline Phytol & 16.19 & 3.75 \\
\hline Dicyclooctanopyridazine & 17.83 & 0.77 \\
\hline I sophthalic acid, 4-methoxyphenyl propyl ester & 19.46 & 0.77 \\
\hline Squalene & 22.23 & 8.29 \\
\hline (1S,2R,4aR,6aR,6bS,12aS,14bR)-1,2,4a,6a,6b,9,12a-Heptamethyl-1,2,3,4,4a,5 & 26.14 & 1.26 \\
\hline 7-Dehydrodiosgenin & 27.54 & 1.23 \\
\hline Cholesterol & 29.06 & 3.46 \\
\hline Stigmasterol & 33.29 & 16.16 \\
\hline$\gamma$-Sitosterol & 35.74 & 15.93 \\
\hline$\beta$-Amyrone & 36.16 & 2.72 \\
\hline$\beta$-Amyrin & 37.49 & 3.40 \\
\hline Spinasterone & 38.59 & 0.45 \\
\hline Stigmast-4-en-3-one & 41.88 & 2.52 \\
\hline
\end{tabular}


This is a fairly typical composition of ethanolic extract of Asteraceae family. However, the sterol content is higher. Apparently, this higher content is connected with the environmental conditions of G. uliginosum L. growth. Twenty constituents were identified in EOG (Table-2). Essential oil consisted of monoterpenic hydrocarbons $50.48 \%$, oxygen-containing monoterpenes $16.51 \%$, including monoterpenols $10.51 \%$, sesquiterpene hydrocarbons $1.52 \%$, terpene esters $0.56 \%$, aromatic compounds $25.08 \%$ and fatty acid esters $5.9 \%$. The major components were $\alpha$-pinene and estragole $53.98 \%$.

It should be noted that the essential oil contains high amount of eucalyptol, in this, it is not different from other

\begin{tabular}{ccc}
\multicolumn{3}{c}{ TABLE-2 } \\
\multicolumn{3}{c}{ CHEMICAL COMPOSITION OF } \\
\hline Constituent & $\mathrm{RR}_{\mathrm{t}}$ & $\%$ of total \\
\hline Tricyclene & 3.61 & 0.33 \\
$\alpha$-Pinene & 3.75 & 32.39 \\
Camphene & 3.99 & 2.56 \\
$\alpha$-Sabinene & 4.25 & 0.31 \\
$\beta$-Pinene & 4.37 & 6.79 \\
3-Carene & 4.74 & 1.91 \\
p-Cymene & 5.00 & 3.49 \\
D-Limonene & 5.04 & 5.01 \\
Eucalyptol & 5.13 & 6.00 \\
$\gamma$-Terpinene & 5.43 & 0.88 \\
$\alpha$-Terpinene & 5.81 & 0.30 \\
Linalool & 5.98 & 3.85 \\
(+)-Camphor & 6.83 & 4.39 \\
Camphol & 7.12 & 1.05 \\
Terpinen-4-ol & 7.19 & 1.22 \\
Estragole & 7.43 & 21.59 \\
Bornyl acetate & 8.43 & 0.56 \\
Caryophyllene & 10.05 & 0.96 \\
(E)- $\alpha$-Bisabolene & 11.21 & 0.51 \\
Isopropyl myristate & 13.80 & 5.90 \\
\hline & &
\end{tabular}

essential oils. Previous phytochemical investigations of the genus have led to the identification of about 125 chemical constituents in total, including flavonoids, sesquiterpenes, diterpenes, triterpenes, phytosterols, anthraquinones, caffeoylquinic acid derivatives and other compounds [13].

Among all the representatives of the genus Gnaphalium, G. affine is the most studied. More than 77 chemical constituents have been reported to be in this plant, including flavonoids, triterpenes, phytosterols, anthraquinones, caffeoylquinic acid derivatives and other compounds. A detailed phytochemical investigation on the aerial part of G. affine led to the isolation of two new esters of caffeoylquinic acid, together with 35 known compounds [12].

The chemical composition of G. uliginosum L. has not been sufficiently studied. An investigation of the phenolic constituents of G. uliginosum L. was performed [9]. Using GC/MS, stigmasterol, $\beta$-amyrin, sitosterol, $\gamma$-sitosterol, scopoletin, squalene were found in the ethanolic extract of $G$. uliginosum L. aerial part. The presence of these compounds has previously been shown in other species of Gnaphalium genus $[11,13]$.

Antimicrobial activity: The minimal inhibitory concentrations (MICs) of ethanolic extract against human pathogen bacteria and fungi varied from 62.5 to $>1000 \mu \mathrm{g} / \mathrm{mL}$ (Table$3)$. The lowest MICs were established for Gram(+) S. aureus and $B$. cereus. The MBCs and MFCs varied from 250.0 to $>1000 \mu \mathrm{g} / \mathrm{mL}$ with no differences between Gram(+/-). In case of EOG, MICs values varied from 31.3 to $>1000 \mu \mathrm{g} / \mathrm{mL}$, MBCs and MFCs were $1000 \mu \mathrm{g} / \mathrm{mL}$ or more. Activity of $\mathrm{EtOH}$ plant extract against Gram(-) phytopathogen bacteria was the same as in case of human Gram(-) pathogens as well as EOG. The MICs values for ethanolic extract varied from 250.0 to $500 \mu \mathrm{g} / \mathrm{mL}$, MBCs 500.0 to $1000 \mu \mathrm{g} / \mathrm{mL}$; for EOG 500.0 and $1000 \mu \mathrm{g} / \mathrm{mL}$, respectively. It is already known that Gram+ bacteria are more susceptible to plant extracts as compared to Gram(-) due to the

TABLE-3

ANTIMICROBIAL ACTIVITY OF THE ETHANOLIC PLANT EXTRACT AND ESSENTIAL OIL FROM Gnaphalium uliginosum L. AGAINST HUMAN AND PHYTOPATHOGENS

\begin{tabular}{|c|c|c|c|c|c|c|}
\hline Microbial strains & MIC & MBC/MFC & MIC & MBC/MFC & MIC & MBC/MFC \\
\hline \multicolumn{7}{|c|}{ Human pathogen bacteria } \\
\hline & \multicolumn{2}{|c|}{ EtOH extract $(\mu \mathrm{g} / \mathrm{mL})$} & \multicolumn{2}{|c|}{ EOG $(\mu \mathrm{g} / \mathrm{mL})$} & \multicolumn{2}{|c|}{ Norfloxacin $(\mu \mathrm{g} / \mathrm{mL})$} \\
\hline Staphylococcus aureus & $62.5 \pm 6.0$ & $250.0 \pm 15.0$ & $31.3 \pm 2.5$ & $1000.0 \pm 10.0$ & $2.4 \pm 0.25$ & $2.4 \pm 0.0019$ \\
\hline Bacillus cereus & $62.5 \pm 5.0$ & $>1000$ & $1000.0 \pm 100.0$ & $>1000$ & $7.8 \pm 0.78$ & $15.6 \pm 1.25$ \\
\hline Escherichia coli & $500.0 \pm 41.0$ & $1000.0 \pm 10.0$ & $500.0 \pm 50.0$ & $1000.0 \pm 5.0$ & $1.5 \pm 0.15$ & $1.5 \pm 0.14$ \\
\hline Pseudomonas aeruginosa & $>1000$ & $>1000$ & $1000.0 \pm 100.0$ & $>1000$ & $3 \pm 0.025$ & $15.6 \pm 1.2$ \\
\hline \multicolumn{7}{|c|}{ Human pathogen fungi } \\
\hline & \multicolumn{2}{|c|}{ EtOH extract $(\mu \mathrm{g} / \mathrm{mL})$} & \multicolumn{2}{|c|}{ EOG $(\mu \mathrm{g} / \mathrm{mL})$} & \multicolumn{2}{|c|}{ Ketoconazole $(\mu \mathrm{g} / \mathrm{mL})$} \\
\hline Candida albicans & $125.0 \pm 12.5$ & $250.0 \pm 23.0$ & $>1000$ & $>1000$ & $3.9 \pm 0.37$ & $3.9 \pm 0.33$ \\
\hline \multicolumn{7}{|c|}{ Phytopathogen bacteria strains } \\
\hline & \multicolumn{2}{|c|}{ EtOH extract $(\mu \mathrm{g} / \mathrm{mL})$} & \multicolumn{2}{|c|}{ EOG $(\mu \mathrm{g} / \mathrm{mL})$} & \multicolumn{2}{|c|}{ Chloramphenicol $(\mu \mathrm{g} / \mathrm{mL})$} \\
\hline Agrobacterium tumefaciens & $500.0 \pm 40.0$ & $1000.0 \pm 80.0$ & $500.0 \pm 47.0$ & $1000.0 \pm 50.0$ & $250 \pm 22.5$ & $500 \pm 42.2$ \\
\hline Erwinia amylovora & $250.0 \pm 22.0$ & $1000.0 \pm 50.0$ & $500.0 \pm 21.0$ & $1000.0 \pm 90.0$ & $250 \pm 21.5$ & $250 \pm 20$ \\
\hline Erwinia carotovora & $250.0 \pm 20.0$ & $500.0 \pm 35.0$ & $500.0 \pm 45.0$ & $1000.0 \pm 10.0$ & $125 \pm 12.3$ & $125 \pm 11.5$ \\
\hline Xanthomonas arboricola & $500.0 \pm 45.0$ & $1000.0 \pm 90.0$ & $500.0 \pm 35.0$ & $1000.0 \pm 30.0$ & $250 \pm 23.1$ & $500 \pm 35.6$ \\
\hline \multicolumn{7}{|c|}{ Phytopathogen fungi strains } \\
\hline & \multicolumn{2}{|c|}{ EtOH extract $(\mu \mathrm{g} / \mathrm{mL})$} & \multicolumn{2}{|c|}{ EOG $(\mu \mathrm{g} / \mathrm{mL})$} & \multicolumn{2}{|c|}{ Difenoconazole $(\mu \mathrm{g} / \mathrm{mL})$} \\
\hline Alternaria solani & $62.5 \pm 5.5$ & $125.0 \pm 12.5$ & $250.0 \pm 12.0$ & $>1000$ & $1.9 \pm 0.15$ & $31.3 \pm 3.1$ \\
\hline Fusarium graminearium & $125.0 \pm 21.0$ & $250.0 \pm 10.0$ & $>1000$ & $>1000$ & $3.9 \pm 0.35$ & $62.5 \pm 5.9$ \\
\hline Fusarium culmorum & $250.0 \pm 22.0$ & $250.0 \pm 47.0$ & $>1000$ & $>1000$ & $3.9 \pm 0.22$ & $125 \pm 11.1$ \\
\hline Phytophtota sp. & $125.0 \pm 19.0$ & $250.0 \pm 25.0$ & $125.0 \pm 110.0$ & $>1000$ & $7.8 \pm 0.75$ & $7.8 \pm 0.68$ \\
\hline
\end{tabular}


permeability barrier provided by the outer membrane or the presence in the periplasmic space of enzymes that are able to break down molecules introduced from outside [7].

Among phytopathogen fungi the most sensitive to ethanolic extract was A. solani MIC $62.5 \mu \mathrm{g} / \mathrm{mL}$, to EOG Phytophtota sp. $125 \mu \mathrm{g} / \mathrm{mL}$. The ethanolic extract and EOG were inactive against $P$. aeruginos $a$ at the highest tested concentration (1000 $\mu \mathrm{g} / \mathrm{mL}$ ). According to Van Vuuren and Holl [21] in most cases the antimicrobial activity of ethanolic extract can be estimated as moderate activity (MIC values, $100-625 \mu \mathrm{g} / \mathrm{mL}$ ) and for three microbial strains (S. aureus, B. cereus and A. solani) as significant activity (less than $100 \mu \mathrm{g} / \mathrm{mL}$ ). The EOG had a moderate antibiotic activity at $500-1000 \mu \mathrm{g} / \mathrm{mL}$, and strong at $101-500$ $\mu \mathrm{g} / \mathrm{mL}[21]$.

Less information is available concerning the antimicrobial activity of the studied plant species of Gnaphalium genus, especially against phytopathogen. Wat et al. [22] did not reveal an antimicrobial effect of G. uliginosum L. ethanolic extract on E. coli, S. cereuisiae and C. albicans, however, they used the disk diffusion method.

The antibacterial activity of ethanolic extract may be related to the high level of known components with antibiotic
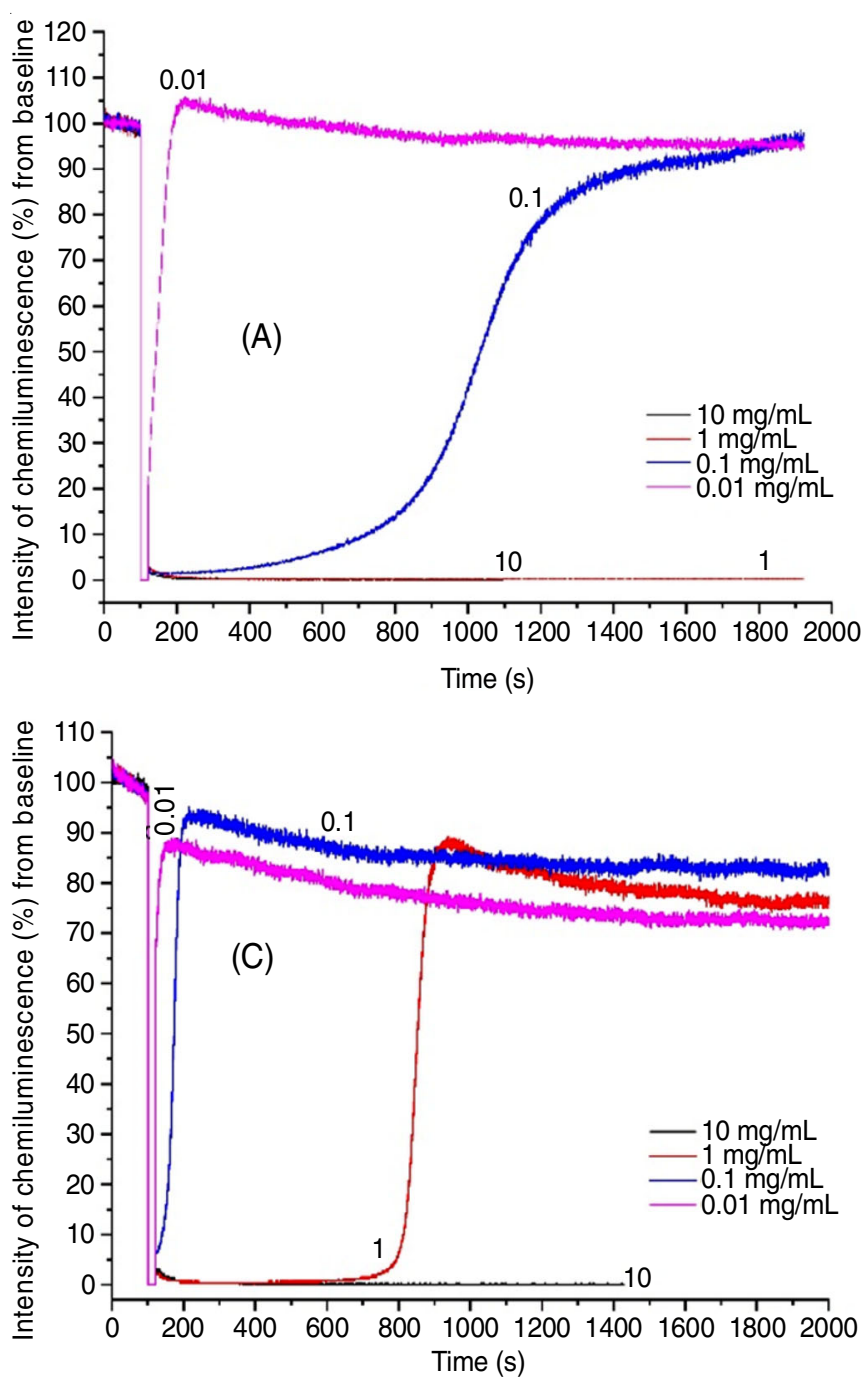

properties as phytol against E. coli, S. typhimurium, S. aureus, antifungicidal viz. C. albicans, A. niger [23-26]; squalene against $S$. aureus [27]; $\beta$-amyrin against B. subtilis, S. aureus, E. coli, S. typhimurium, in total they make up $15.44 \%[28,29]$.

In case of EOG, the major components with set antimicrobial activity are cymene against Bacillus cereus [30]; D-limonene had a high inhibitory effect on the growth of $E$. coli, S. aureus, B. subtilis, S. cerevisiae [31]; 1,8-cineole against A. carbonarius [32]; $\gamma$-terpinene had significant antibacterial activity against $X$. oryzaepv. oryzae [33]; linalool [34,35]; camphor against S. epidermidis, E. faecalis and S. aureus [36]; terpinen-4-ol showed antifungal activity against strains of $C$. posadasii, $H$. capsulatum and $H$. capsulatum [37]; $\beta$-caryophyllene inhibited the growth of S. mutans [38]. For other species of Gnaphalium genus the antibacterial activity was also shown $[11,13]$.

Antioxidant activity: The values of TRAP and TAR obtained from the quenching of luminol-enhanced chemiluminescence in vitro are shown in Fig. 1 (Table-4). The chemiluminescence kinetics revealed a higher antioxidant activity of ethanolic extract in comparison with Trolox, both in terms of TRAP and TAR (Figs. 1A, 1C). The ethanolic extract was inferior to
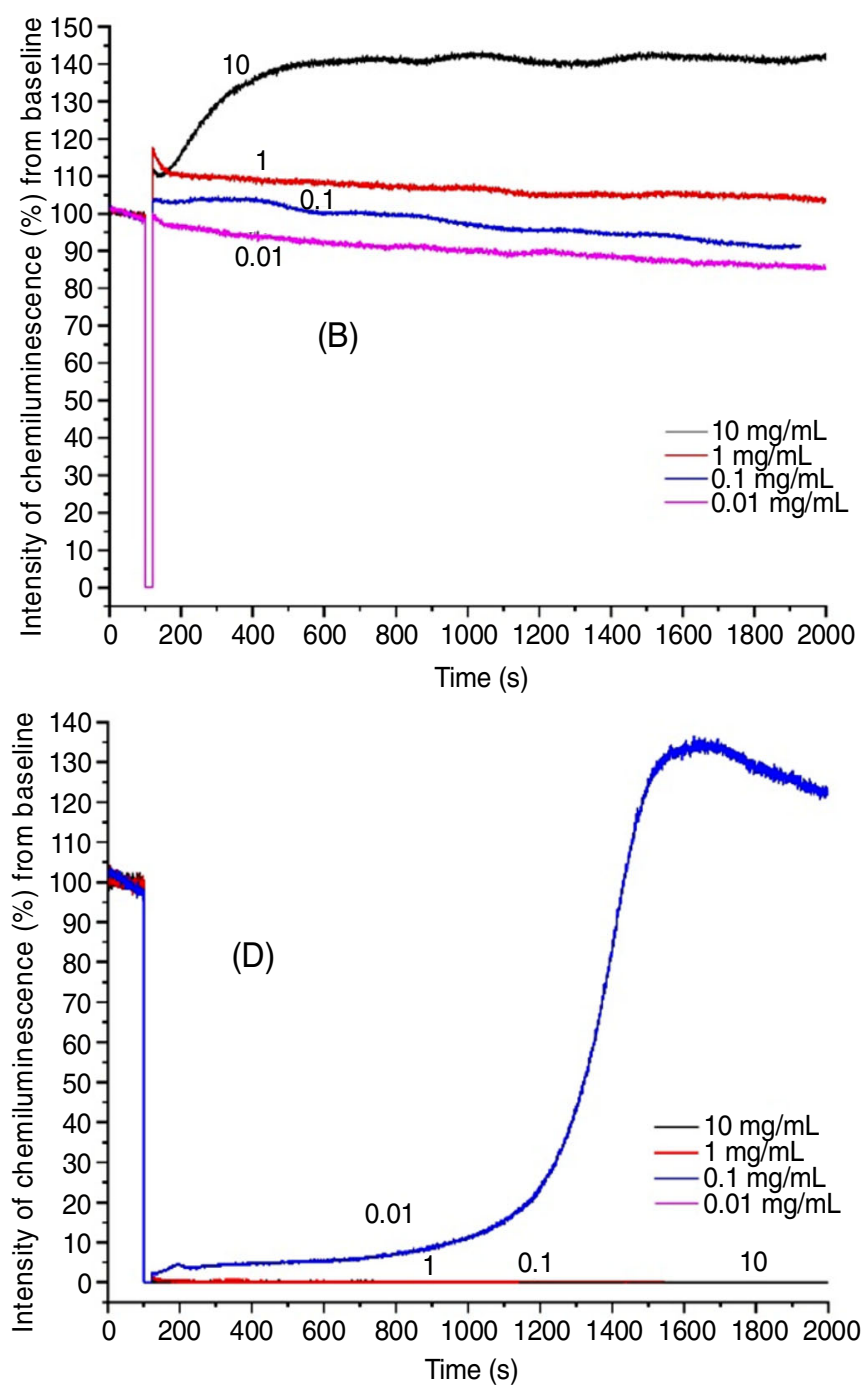

Fig. 1. Chemiluminescence of ethanolic plant extract (A), essential oil from Gnaphalium uliginosum L. (B), Trolox (C) and quercetin (D) intensity of light emission vs. time. The numbers beside the curves are the concentrations of Gnaphalium uliginosum L. essential oil, ethanolic plant extract and Trolox ( $\mathrm{mg} / \mathrm{mL}$ ). Time (s) is plotted on the abscissa axis and chemiluminescence intensity (a.u.) is plotted on the ordinate axis 
TABLE-4

TRAP AND TAR VALUES FOR ETHANOLIC PLANT EXTRACT AND ESSENTIAL OIL FROM Gnaphalium uliginosum L.

\begin{tabular}{|c|c|c|c|c|c|}
\hline \multirow{2}{*}{ Method } & \multirow{2}{*}{$\begin{array}{c}\text { Concentration } \\
(\mathrm{mg} / \mathrm{mL})\end{array}$} & \multicolumn{2}{|c|}{ Gnaphalium uliginosum L. } & \multirow{2}{*}{ Trolox } & \multirow{2}{*}{ Quercetin } \\
\hline & & $\mathrm{EtOH}$ & EOG & & \\
\hline \multirow{4}{*}{ TRAP (s) } & 10 & $1500+$ & $4000+$ & $1500+$ & $4000+$ \\
\hline & 1 & $2000+$ & 36 & 450 & $4000+$ \\
\hline & 0.1 & 167 & 30 & 10 & $1500+$ \\
\hline & 0.01 & 0 & 0 & 0 & 149.4 \\
\hline \multirow{4}{*}{ TAR (\%) } & 10 & 99.94 & -44 & 99.9 & 99.5 \\
\hline & 1 & 99.66 & -24 & 25 & 99.5 \\
\hline & 0.1 & 2.8 & -9 & 18 & 98.9 \\
\hline & 0.01 & -4.66 & 0.57 & 29 & -37.5 \\
\hline
\end{tabular}

quercetin in terms of TRAP index: the lag phase of quercetin was significantly longer at all studied concentrations. Quercetin at concentration $0.01 \mathrm{mg} / \mathrm{mL}$ increased the intensity of chemiluminescence by $37.5 \%$ compared to the initial level, promoting the formation of free radicals in the system (prooxidant effect) (Fig. 1D). On the contrary, in the case of ethanolic extract the antioxidant potential was exhausted, after which the level of chemiluminescence stabilized without antioxidant (no prooxidant effect).

Essential oil was found to have antioxidant properties in concentrations less than $0.1 \mathrm{mg} / \mathrm{mL}$ only (Fig. 1B): free radicals were insignificantly scavenged, the luminescence intensity decreased compared to the initial level. The EOG promoted a quick flash of free radical formation. At $0.1 \mathrm{mg} / \mathrm{mL}$ and more the EOG acted as a prooxidant due to branching chain reaction. The EtOH plant extract acts as medium-strength antioxidant at concentrations of less than $0.1 \mathrm{mg} / \mathrm{mL}$.

Plants are the main source of natural antioxidants. Their secondary metabolites often have multiple effects and can be widely used. Apparently the antioxidant components of ethanolic extract, capable of scavenging free radicals, were $\beta$-amyrin [28,29], squalene [39], phytol [24-26], scopoletin [40,41]. These compounds reached $19.62 \%$ of the total amount. They have a significant antioxidant activity individually; also, synergism between the components is possible.

\section{Conclusion}

This study confirms the potential use of ethanolic extract Gnaphalium uliginosum L. and essential oil as an alternative, natural source of plant-based bactericides, fungicides and antioxidant substances. The phytochemical compositions of ethanolic extract and the essential oil were fairly typical for a member of the Asteraceae family. The antibacterial and antifungal activities of ethanolic extract and the essential oil were observed for human and plant pathogens in most cases and varied from moderate to strong. The antioxidant activity of ethanolic extract was higher than that of the essential oil. The most bioactive constituents of ethanolic extract are squalene, phytol, $\beta$-amyrin, scopoletin, essential oil viz. cymene, D-limonene, 1,8-cineole, $\gamma$-terpinene, linalool, camphor, terpinen-4-ol and $\beta$-caryophyllene.

\section{ACKNOWLEDGEMENTS}

The authors are grateful to the staff of Distributed SpectralAnalytical Center of Shared Facilities for isolated compounds analysis. Thanks are also due to Laboratory of Chemical and Biological Research, Laboratory of Microbiology of Federal
Research Center of Kazan Scientific Center of Russian Academy of Sciences for their assistance in discussing the results.

\section{CONFLICT OF INTEREST}

The authors declare that there is no conflict of interests regarding the publication of this article.

\section{REFERENCES}

1. M.M. Meela, L.K. Mdee, P. Masoko and J.N. Eloff, S. Afr. J. Bot., 442 (2019);

https://doi.org/10.1016/j.sajb.2018.12.007.

2. N. Akhtar, H. ul-Ihsan and B. Mirza, Arab. J. Chem., 11, 1223 (2018); https://doi.org/10.1016/j.arabjc.2015.01.013.

3. A.R.H. da Silva L.Q.S. Lopes, G.B. Cassanego, P.R. de Jesus, K.C. Figueredo, R.C.V. Santos, G. Lopes and L.D. Bauermann, Biomed. J. 41, 194 (2018); https://doi.org/10.1016/j.bj.2018.04.006.

4. P. Wikaningtyas and E.Y. Sukandar, Asian Pac. J. Trop. Biomed., 6, 16 (2016);

https://doi.org/10.1016/j.apjtb.2015.08.003.

5. T. Hintz, K.K. Matthews and R. Di, Biomed Res. Int., 2015, Article ID 246264 (2015);

https://doi.org/10.1155/2015/246264.

6. S. Kharchoufi, F. Licciardello, L. Siracusa, G. Muratore, M. Hamdi, and C. Restuccia, Ind. Crops Prod. 111, 345 (2018); https://doi.org/10.1016/j.indcrop.2017.10.037.

7. A. Scavo, G. Pandino, C. Restuccia, L. Parafati, G. Cirvilleri and G. Mauromicale, Ind. Crops Prod., 129, 206 (2019); https://doi.org/10.1016/j.indcrop.2018.12.005.

8. A.G. Borisova, V.P. Bochantsev, I.T. Vasilchenko, et al., ed.: V.L. Komarov, Gnaphallium L., Flora of the USSR, Publishing House of the Academy of Sciences, Moskow, Leningrad, pp. 381-404 (1959).

9. A.N. Shikov, M. Kundracikova, T.L. Palama, O.N. Pozharitskaya, V.M. Kosman, V.G. Makarov, B. Galambosi, H.J. Kim, Y.P. Jang, Y.H. Choi and R. Verpoorte, Phytochem. Lett., 3, 45 (2010); https://doi.org/10.1016/j.phytol.2009.11.002.

10. A.N. Shikov, O.N. Pozharitskaya, V.G. Makarov, H. Wagner, R. Verpoorte and M. Heinrich, J. Ethnopharmacol., 154, 481 (2014); https://doi.org/10.1016/j.jep.2014.04.007.

11. R. Villagómez, M. Sánchez, O. Espejo, A. Zúñiga-Estrada, J.M. TorresValencia and P. Joseph-Nathan, Fitoterapia, 72, 692 (2001); https://doi.org/10.1016/S0367-326X(01)00303-3.

12. W. Zhang, C.Z. Wu and S.Y. Fan, Chin. J. Nat. Med., 16, 347 (2018); https://doi.org/10.1016/S1875-5364(18)30066-9.

13. X. Zheng, W. Wang, H.S. Piao, W.Q. Xu, H.B. Shi and C.G. Zhao, Molecules, 18, 8298 (2013); https://doi.org/10.3390/molecules 18078298.

14. CLSI, Methods for Dilution Antimicrobial Susceptibility Tests for Bacteria that Grow Aerobically, CLSI: Wayne, Pennsylvania, USA (2018).

15. V. Kanagarajan, M.R. Ezhilarasi and M. Gopalakrishnan, Org. Med. Chem. Lett., 1, 8 (2011); https://doi.org/10.1186/2191-2858-1-8.

16. NCCLS, Reference Method for Broth Dilution Antifungal Susceptibility Testing of Yeasts, In: Approved Standard Wayne, Pennsylvania, USA, edn 2 (2002). 
17. V.E. Semenov, A.D. Voloshina, N.V. Kulik, A.S. Strobykina, R.K. Giniyatullin, L.F. Saifina, A.E. Nikolaev, E.S. Krylova, V.V. Zobov, and V.S. Reznik, Russ. Chem. Bull., 64, 2885 (2015); https://doi.org/10.1007/s11172-015-1243-5.

18. A. Krasowska, D. Rosiak, K. Szkapiak and M. Lukaszewicz, Curr. Top. Biophys., 24, 89 (2000).

19. A.B. Vyshtakalyuk, V.E. Semenov, I.A. Sudakov, K.N. Bushmeleva, L.F. Gumarova, A.A. Parfenov, N.G. Nazarov, I.V. Galyametdinova and V. Zobov, Russ. Chem. Bull., 67, 705 (2018); https://doi.org/10.1007/s11172-018-2126-3.

20. C. Desmarchelier, M. Repetto, J. Coussio, S. Llesuy and G. Ciccia, Int. J. Pharmacogn., 35, 288 (1997); https://doi.org/10.1076/phbi.35.4.288.13303.

21. S. Van Vuuren and D. Holl, J. Ethnopharmacol., 208, 236 (2017); https://doi.org/10.1016/j.jep.2017.07.011.

22. K.C. Wat, T. Johns and G.H.N. Towers, J. Ethnopharmacol., 2, 279 (1980); https://doi.org/10.1016/S0378-8741(80)81006-3.

23. M.T. Ghaneian, M.H. Ehrampoush, A. Jebali, S. Hekmatimoghaddam and M. Mahmoudi, Environ. Health Eng. Manag. J., 2, 13 (2015).

24. M.T. Islam, E.S. Ali, S.J. Uddin, S. Shaw, M.A. Islam, M.I. Ahmed, M.C. Shill, U.K. Karmakar, N.S. Yarla, I.N. Khan, M.M. Billah, M.D. Pieczynska, G. Zengin, C. Malainer, F. Nicoletti, D. Gulei, I. BerindanNeagoe, A. Apostolov, M. Banach, A.W.K. Yeung, A. El-Demerdash, J.B. Xiao, P. Dey, S. Yele, A. Jozwik, N. Strzalkowska, J. Marchewka, K.R.R. Rengasamy, J. Horbanczuk, M.A. Kamal, M.S. Mubarak, S.K. Mishra, J.A. Shilpi and A.G. Atanasov, Food Chem. Toxicol., 121, 82 (2018); https://doi.org/10.1016/j.fct.2018.08.032.

25. M.T. Islam, M.V.O.B. de Alencar, K. da Conceição Machado, K. da Conceição Machado, A.A. de Carvalho Melo-Cavalcante, D.P. de Sousa and R.M. de Freitas, Chem. Biol. Interact., 240, 60 (2015); https://doi.org/10.1016/j.cbi.2015.07.010.

26. S.P. Prabha, C. Karthik and S.H. Chandrika, Biocatal. Agric. Biotechnol., 17, 736 (2019); https://doi.org/10.1016/j.bcab.2019.01.026.

27. B.C. Bindu, D.P. Mishra and B. Narayan, J. Funct. Foods, 18, 224 (2015); https://doi.org/10.1016/j.jff.2015.07.008.

28. N. Abdel-Raouf, N.M. Al-Enazi, A.A. Al-Homaidan, I.B.M. Ibraheem, M.R. Al-Othman and A.A. Hatamleh, Arab. J. Chem., 8, 32 (2015); https://doi.org/10.1016/j.arabjc.2013.09.033.
29. C. Sunil, S.S. Irudayaraj, V. Duraipandiyan, N.A. Al-Dhabi, P. Agastian, and S. Ignacimuthu, Ind. Crops Prod., 61, 510 (2014); https://doi.org/10.1016/j.indcrop.2014.07.005.

30. B. Delgado, P.S. Fernandez, A. Palop and P.M. Periago, Food Microbiol., 21, 327 (2004); https://doi.org/10.1016/S0740-0020(03)00075-3.

31. M.R. Zahi, H. Liang and Q.P. Yuan, Food Control, 50, 554 (2015); https://doi.org/10.1016/j.foodcont.2014.10.001.

32. I. Dammak, Z. Hamdi, S.K. El Euch, H. Zemni, A. Mliki, M. Hassouna and S. Lasram, Ind. Crops Prod., 128, 85 (2019); https://doi.org/10.1016/j.indcrop.2018.11.006.

33. K. Yoshitomi, S. Taniguchi, K. Tanaka, Y. Uji, K. Akimitsu and K. Gomi, J. Plant Physiol., 191, 120 (2016); https://doi.org/10.1016/j.jplph.2015.12.008.

34. A. Duarte, A. Luis, M. Oleastro and F.C. Domingues, Food Control, 61, 115 (2016); https://doi.org/10.1016/j.foodcont.2015.09.033.

35. A. Prakash, V. Vadivel, D. Rubini and P. Nithyanand, Food Biosci., 28, 57 (2019); https://doi.org/10.1016/i.fbio.2019.01.018.

36. T. Chaturvedi, A. Kumar, A. Kumar, R.S.Verma, R.C. Padalia, V. Sundaresan, A. Chauhan, D. Saikia, V.R. Singh and K.T. Venkatesha, Ind. Crops Prod., 118, 246 (2018); https://doi.org/10.1016/j.indcrop.2018.03.050.

37. R.S.N. Brilhante, E.P. Caetano, R.A.C. de Lima, F.J.D. Marques, D. CasteloBranco, C.V.S. de Melo, G.M.D. Guedes, J.S. de Oliveira, Z.P. de Camargo, J.L.B. Moreira, A.J. Monteiro, T. Bandeira, R.D. Cordeiro, M.F.G. Rocha and J.J.C. Sidrim, Braz. J. Microbiol., 47, 917 (2016); https://doi.org/10.1016/j.bjm.2016.07.015.

38. H.J. Yoo and S.K. Jwa, Arch. Oral Biol., 88, 42 (2018); https://doi.org/10.1016/j.archoralbio.2018.01.009.

39. S.K. Kim and F. Karadeniz, Adv. Food Nutr. Res., 65, 223 (2012); https://doi.org/10.1016/B978-0-12-416003-3.00014-7.

40. X.T. Cai, J. Yang, J.P. Zhou, W.G. Lu, C.P. Hu, Z.H. Gu, J.G. Huo, X.N. Wang and P. Cao, Bioorg. Med. Chem., 21, 84 (2013); https://doi.org/10.1016/j.bmc.2012.10.059.

41. S. Jamuna, K. Karthika, S. Paulsamy, K. Thenmozhi, S. Kathiravan, and R. Venkatesh, Ind. Crops Prod., 70, 221 (2015); https://doi.org/10.1016/j.indcrop.2015.03.039. 